\title{
Scott Fitzgerald: famous writer, alcoholism and probable epilepsy
}

Scott Fitzgerald: famoso escritor, alcoolismo e provável epilepsia

Mariana M. Wolski', Luciano de Paola', Hélio A. G. Teive'

\begin{abstract}
Scott Fitzgerald, a world-renowned American writer, suffered from various health problems, particularly alcohol dependence, and died suddenly at the age of 44. According to descriptions in A Moveable Feast, by Ernest Hemingway, Fitzgerald had episodes resembling complex partial seizures, raising the possibility of temporal lobe epilepsy.
\end{abstract}

Keywords: Scott Fitzgerald; alcoholism; epilepsy.

RESUMO

Scott Fitzgerald, reconhecido escritor americano, mundialmente famoso, apresentou vários problemas de saúde, particularmente a sua dependência ao álcool, tendo morte súbita aos 44 anos de idade. Relatos publicados no livro de Ernest Hemingway "Paris é uma festa” dão conta de que Scott Fitzgerald apresenta prováveis crises parciais complexas, sugerindo a hipótese de epilepsia do lobo temporal.

Palavras-chave: Scott Fitzgerald; alcoolismo; epilepsia.

In the history of literature, various great writers, such as the Russian, Fyodor Dostoevsky, and the Brazilian, Machado de Assis, were diagnosed with epilepsy during their lifetimes ${ }^{1,2}$. A more detailed analysis of their biographies depicts descriptions of the psychological suffering inflicted by this condition, which at the same time served as raw material for their works and thus exerted a major influence on them in various ways ${ }^{1,2,3,4}$. F. Scott Fitzgerald, a world-renowned writer, died at an early age from alcoholism and its comorbidities ${ }^{5}$. In his famous book $A$ Moveable Feast, Ernest Hemingway, one of Fitzgerald's closest friends, described episodes compatible with complex partial seizures, making epilepsy a plausible diagnosis for the latter 6 .

\section{SCOTT FITZGERALD - A SHORT BIOGRAPHY}

Francis Scott Key Fitzgerald (Figure) was born in 1896 in Saint Paul, Minnesota, USA. After serving in World War I as a volunteer, he embarked on a literary career ${ }^{5}$. He belonged to the famous "Lost Generation" of the 1920s, a group of writers and artists who lived in Paris between the end of the World War I and the great depression.

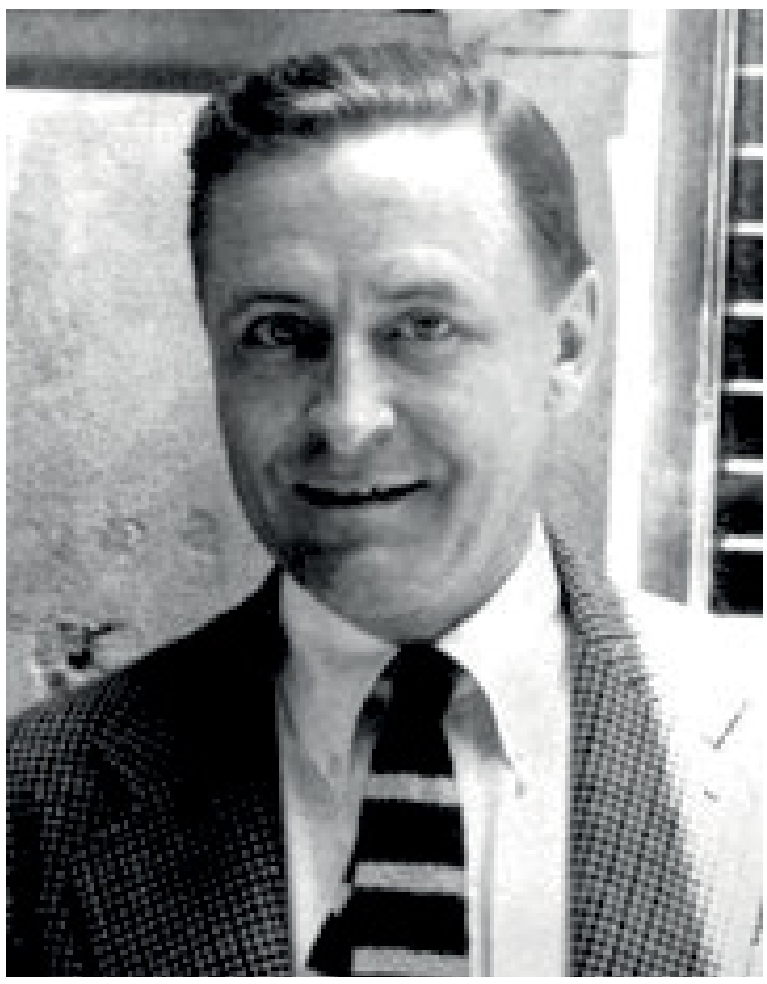

(Reproduced from Google Images - www.nytimes.com, July 28th, 2016). Figure. F. Scott Fitzgerald (1896 - 1940). 
The group included Ernest Hemingway, Ezra Pound, T. S. Eliot and James Joyce ${ }^{5,6,7}$. He married Zelda Sayre, whose medical history is associated with a number of psychiatric problems, including schizophrenia ${ }^{5}$. His most famous novels are The Great Gatsby, Tender is the Night, The Beautiful and Damned and The Last Tycoon, and his short stories include The Curious Case of Benjamin Button, recently made into a famous movie ${ }^{5}$. Fitzgerald died suddenly in 1940 at the age of 44 in Los Angeles, California, USA, from a heart attack caused by a heart condition probably brought about by complications of alcohol abuse $\mathrm{e}^{5,7,8}$.

\section{Alcoholism and comorbidities}

Scott Fitzgerald became an alcohol addict at a very young age, and his addiction worsened significantly when he lived in Paris ${ }^{5,6,7,8}$. A number of references support the concurrence of comorbidities, such as a sleep disorder, anxiety, depression, hypochondria and pulmonary tuberculosis ${ }^{5,7,8}$. His biographers stated that he was known to use barbiturates and sedatives in a generous way $^{5,7}$. In the last years of his life, while living and working in Hollywood, LA, he developed signs and symptoms of heart failure due to alcoholic cardiomyopathy and died suddenly in $1940^{5}$. All the health problems from which Scott Fitzgerald and his wife, Zelda, suffered had a profound influence on his literary career ${ }^{5,8}$. In the 1930s, he published six stories involving hospitals and healthcare professionals ("doctor-nurse" stories), as well as nine stories on medical themes ${ }^{8}$.

Paris, a moveable feast and the epilepsy hypothesis

In Paris, Fitzgerald became very close friends with Ernest Hemingway, one of the most famous and important writers of all times and winner of the Nobel Prize in Literature in $1961^{6}$.

In his well-known book A Moveable Feast, Hemingway describes an episode, which in its sequence, resembles a seizure and leads to the presumption of epilepsy ${ }^{6}$ :

“...The first time I ever met Scott Fitzgerald, a very strange thing happened. Many strange things happened with Scott but this one I was never able to forget." ${ }^{6}$

In his book, Hemingway describes an incident when they were both in a bar, drinking together with another friend (Dunc Chaplin):

"...Now I looked back at his face again and it was then that the strange thing happened" ${ }^{6}$

"...As he sat there at the bar holding the glass of champagne the skin seemed to tighten over his face until all the puffiness was gone and then it drew tighter until the face was like a death's head. The eyes sank and began to look dead and the lips were drawn tight and the color left the face so that it was the color of used candle wax. This was not my imagination. His face became a true death's head, or death mask, in front of my eyes."

“...- "Scott", I said. "Are you all right?" He did not answer and his face looked more drawn than ever. We'd better get him to a first aid station, I said to Dunc Chaplin. No. He's all right. He looks like he is dying. No. That's the way it takes him. We got him into a taxi and I was very worried but Dunc said he was all right and not to worry about him. He'll probably be all right by the time he gets home, he said".

Hemingway then describes Fitzgerald experiencing what could be a prolonged post-seizure confusional period, as well as, post-seizure amnesia. The book includes a description of a further similar episode, also triggered by excessive alcohol consumption ${ }^{6}$.

In his biography of Scott Fitzgerald published in 1994, Jeffrey Meyers notes that Fitzgerald was seen by various physicians due to his seizures and that alcohol-induced hypoglycemia was considered the probable diagnosis 5 .

\section{DISCUSSION}

The episodes that Scott Fitzgerald had could have been epileptic, syncopal, psychogenic non-epileptic, transient ischemic attack, or even physiologic non-epileptic, as the result of hypoglycemia, for instance. Nevertheless, the very detailed description in Hemingway's book suggests that they were complex partial seizures probably caused by temporal lobe epilepsy ${ }^{6}$. As per the description, there is no evidence to suggest alcohol-induced hypoglycemia, transient ischemic attack, or even a syncopal event in its fullest, including the classic flaccid loss of consciousness. On the other hand, the abruptness of the onset, the concurrent behavioral arrest, the length of the complete unresponsiveness and prolonged postictal state, associated with complete recovery after a period of sleep, do bring to mind the hypothesis of a complex partial or dyscognitive seizure. People with epilepsy frequently present with several comorbidities, including anxiety, depression, and heart disease ${ }^{9}$. Furthermore, chronic alcohol ingestion induces tolerance and physical dependence ${ }^{10}$, and drug addiction, including alcohol abuse, increases the risk of seizure, lowering the seizure threshold and increasing the chances of prolonged or sustained seizure activity. Sleep deprivation, can be another triggering factor for epileptic seizures ${ }^{10}$. Scott Fitzgerald suffered from severe chronic alcoholism, anxiety, depression, a sleep disorder, and a heart condition, as well as probable complex partial seizures likely triggered by alcohol abuse. 


\section{References}

1. Iniesta I. Epilepsy in Dostoevsky. Prog Brain Res. 2013;205:277-93. doi:10.1016/B978-0-444-63273-9.00014-9

2. Yacubian EM, Caboclo LO. Epilepsy and stigma: an approach to understanding through the life and works of the Brazilian writer Machado de Assis (1839-1908). Epilepsy Behav. 2011;20(3):465-70. doi:10.1016/j.yebeh.2010.12.040

3. Amâncio EJ. Dostoevsky and Stendhal's syndrome. Arq Neuropsiquiatr. 2005;63(4):1099-103. doi:10.1590/S0004-282X2005000600034

4. Guerreiro CA. Machado de Assis's epilepsy. Arq Neuropsiquiatr. 1992;50(3):378-82. doi:10.1590/S0004-282X1992000300020

5. Meyers J. Scott Fitzgerald: a biography. New York: Harper Perennial; 2014

6. Hemingway E. A moveable feast. London: Arrow; 2004.
7. Kerr L. A lost decade: exploring F. Scott Fitzgerald's contribution to the illness canon through the doctor-nurse series and other healthcare stories of the 1930s. Med Humanit. 2012;38(2):83-7. doi:10.1136/medhum-2012-010190

8. Monteiro G. Fitzgerald vs Fitzgerald: "an alcoholic case". Lit Med. 1987;6(1):110-6. doi:10.1353//m.2011.0010

9. Keezer MR, Sisodiya SM, Sander JW. Comorbidities of epilepsy: current concepts and future perspectives. Lancet Neurol. 2016;15(1):106-15. doi:10.1016/S1474-4422(15)00225-2

10. Leach JP, Mohanraj R, Borland W. Alcohol and drugs in epilepsy: pathophysiology, presentation, possibilities, and prevention. Epilepsia. 2012;53 (s4):48-57. doi:10.1111/j.1528-1167.2012.03613.x 